\title{
EXPERIMENTAL EVALUATION OF DOXORUBICIN DRUG AS ANTICANCER AGENT USING A NATURAL COMPONENT: AN IN VIRTO STUDY
}

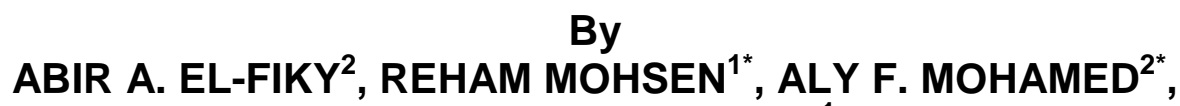 \\ And ESRAA M. WAHBA ${ }^{1}$
}

Faculty of Biotechnology, October University for Modern Sciences and Arts (MSA), Egypt ${ }^{1}$ and VACSERA, Dokki, Giza ${ }^{2}$

$\left({ }^{*}\right.$ Correspondence: esraa.mohamed11@msa.edu.eg)

\section{Abstract}

HCC is the sixth commonest cancer worldwide and the third one to cause death. In Egypt, liver cancer forms $1.68 \%$ of total malignancies. HCC constitutes $70.48 \%$ of liver tumors. HCC represents the main complication of cirrhosis. Chemotherapy has an undesirable side effect, so the drugs are used instead. Bee venom and curcumin have been used as folk medicine since ancient times. This study examined the anticancer potential of bee (Apis mellifera) venom and curcumin compared with a synthetic anticancer of Doxorubicin (Dox) drug, and tested the effect of combination between the tested three components to decrease the chemotherapy side effect. Cytotoxicity activity of Bee venom and curcumin were determined using MTT assay. Cell cycle was determined by flow cytometry and apoptotic detection by using Annexin V-FITC Assay. RNA was extracted to evaluate the expression of P53, Bcl2 \& NF- $\mathrm{KB}$ genes using semi-quantitative RT-PCR after 24hrs. HepG2 cell line was more save to test bee venom and curcumin onHepG2 cell line. Curcumin and bee venom had $\mathrm{IC}_{50}$ as $15.15 \& 31 \mu \mathrm{g} / \mathrm{ml}$ with $\mathrm{HepG} 2$ cell line. Combination between Bee venom, curcumin, and doxorubicin drug had apoptotic effect against HepG2cell line through the elevation by increasing the level of p53 \& NF-kB genes and decrease the Bcl-2 gene expression.

Keywords: Hepatocellular carcinoma (HCC), Doxorubicin, Bee venom, Curcumin, Combination therapy.

\section{Introduction}

Mortality rates due to HCC have increased in many countries over recent decades. In this study, we updated worldwide mortality trends for HCC from 1990 to 2014, and predicted trends for some countries to 2020, with unfavorable trends in Northern and Central Europe, North and Latin America. East Asia showed an improvement; however mortality rates in this region were 2-to 5fold higher than in most European countries and the Americas. Steady declines to 2020 are predicted for East Asia but not for $\mathrm{Eu}-$ rope and the Americas (Bertuccio et al, 2017). In Egypt, liver cancer forms $11.75 \%$ of the malignancies of all digestive organs and $1.68 \%$ of the total malignancies. HCC constitutes $70.48 \%$ of all liver tumors among Egyptian (Holah et al, 2015). HCC is a malignancy with extremely troubling prospects and a five-year survival rate announced underneath $9 \%$. Hepatocellular carcinoma has increased significantly worldwide, especially in developing countries in Asia, such as China and sub-Saharan Africa. Although, the larger part of HCC cases are a consequence of infections because of the hepatitis $\mathrm{B}$ and $\mathrm{C}$ viruses, hazard factors such as both alcoholic and non-alcoholic, obesity, iron overload, cirrhosis, and in addition dietary hepatocarcinogenesis, such as aflatoxins and nitrosamines have likewise been implicated as critical key reasons of HCC (Darvesh et $a l, 2012)$. Progressed HCC is highly refractive to presently accessible chemotherapies, and patients suffering from HCC regulatory develop drug resistance during treatment. Several chemotherapeutic agents have been tested in patients with cutting-edge HCC however, the results were disappointing and life-threatening side effects frequently limit prolonged treatment (Bagi and Andresen, 2010). One of the chemotherapeutics tested in HCC patients, Doxorubicin is an an- 
thracycline antibiotic that exerts its cytotoxic effects via intercalating between base pairs of the DNA double helix structure and inhibiting the function of topoisomerase II, the enzyme that is responsible for the proper conformation and stability of DNA helix (Mahjoub et al, 2017) that showed rather low efficacy however, with a response rate of $10-15 \%$ and doxorubicin remains the best single specialist as of now accessible (Bagi and Andresen, 2010). The use of traditional drugs is declining and naturally extracted drugs are used instead. Several pharmacological anticancer applications have been found in the bee venom (Alizadehnohi et al, 2017). Although the curcumin has possesses valuable pharmaceutical properties and medicinal benefits (Mahjoub et al, 2017). Many authors have recognized therapeutic potential; as an anti-inflammatory, antioxidant and anti-cancer agent (Sharma et al, 2016).Bee venom from the venom gland located in the abdominal cavity contains several biologically active peptides that including approximately $50 \%$ of melittin and other of mast cell degranulating peptide, apamin, adolapin, and phospholipase A2 enzyme as well as non-peptide components such as norepinephrine, histamine , and dopamine and non-peptide components including lipids, carbohydrates and free amino acids. The effects of bee venom induce poison of apoptosis, necrosis, cytotoxicity, and growth inhibition on cancer cells. BV inhibits proliferation of cancer cell and tumor growth that involve stimulating of the local cellular immune responses in lymph nodes (Oršolić, 2012).Recent studies have demonstrated that natural products can inhibit tumor growth and its metastasis leading to induction of cell apoptosis. Thus, it seemed to consider using these natural products as an alternative new medicine for human cancer. Throughout the past two decades, melittin as a major peptide in bee venom has concerned a huge attention for their potential effect in treating cancer. Melittin is an amphiphilic peptide consisting of 26 amino acid. It is isolated from bee Apis mellifera venom that disturbed the membrane (Trumbeckaite et al, 2015). Curcumin is a yellow pigment extracted from rhizome of turmeric is the crystallization of polyphenols with low molecular weight. Turmeric belongs to a permanent herb called Curcuma longa $L$. which is prevalent in tropical and subtropical regions. The biological characteristic of turmeric is known to be attributed to the content of curcuminoids found in a dense structure of turmeric. Curcumin has an extensive variety of applications as nutritional agent of treatment, food ingredients, and medicine in various diseases (Darveshet al., 2012).Curcumin contains a high plutonobic molecule capable of interacting with many of the molecular targets involved in inflammation. Curcumin has ability to down-regulating of cyclooxygenase-2 (COX-2) and inducible nitric oxide synthase (iNOS) enzymes. The production of cytokines also inhibits inflammation of the tumor necrosis factor-alpha (TNF-a) and monocyte chemo-attractant protein (MCP) .Cox2 and iNOS are most likely inhibited by curcumin suppression of the nuclear factor kappa B (NF-kB) activation NF-kB. The eukaryotic transcription factor is involved everywhere in the regulation of inflammation, cellular proliferation, and transformation .Curcumin is believed to suppress the activation of NF-kB and pro-inflammatory gene expression by inhibiting phosphorylation of inhibitor factor I-Kappa B kinase. The suppression of NF-kB activation later down regulates COX-2 \&iNOS expression, thereby inhibiting the inflammatory process and tumors (Jurenka, 2009). P53, BCL-2, \& NF$\kappa \mathrm{B}$ ex-pression genes played an important role in the control of apoptosis. P53 is a protein which plays a critical role in the intrinsic apoptosis pathway activation (Fesik, 2005). Bcl-2 may act upstream of P53 pathway. The induction of NF- $\kappa \mathrm{B}$ mRNA and protein were found to be stuck in presence of Bcl-2. Cross-like between Bcl-2, p53 and $\mathrm{NF}-\kappa \mathrm{B}$ genes is a significant determinant of 
drug-induced apoptosis (Giménez-Bonafé et al, 2009).

This work evaluated the possible anticancer effects of some natural components such as bee venom and curcumin that compared to a synthetic anticancer drug (doxorubicin). The parameters included cytotoxicity, cell cycle, and the expression of some genes related to apoptosis by semiquantitative RT-PCR technique to show the effect of combination on human cell line.

\section{Material and Methods}

Doxorubicin 50mg/25mL (MYLAN Pharmaceutical Co.) was diluted in RPMI1641 media (Bio-Whittaker ${ }^{\mathrm{TM}}$ Classical Media, Lonza) to prepare test concentrations. Egyptian of bee (Apis mellifera) venom and curcumin were su-pplied from Sera plant VACSERA. Both were dissolved in $2.5 \mathrm{~mL}$ sterile double distilled water to contain $10 \mathrm{mg} / \mathrm{mL}$ and sterilized using $0.22 \mathrm{~m}$ syringe filter (Millipore-USA) and serially diluted in RPMI-1641 media. HepG2 (Human liver cancer cell line) was originally supplied from USA Type culture collection (ATCC). Trypsin $0.25 \%$ was provided by VACSERA-Cell Culture Unit. Cells were seeded at a density of $2 \times 105 / \mathrm{ml}$ and routinely cultured in RPMI-1641 medium in tissue culture flasks (Griener, Germany).

Maintenance of cell line and culture conditions: Hep G2 (Human liver cancer cell line) was provided by VACSERA-Cell Culture Unit, Egypt. Cells were cultured in RPMI medium in T-75 flasks (Griener, Germany) supplemented with $10 \%$ fetal bovine serum. The cell cultures were maintained at $37^{\circ} \mathrm{C}$, 95\% humidified atmosphere with $5 \% \mathrm{CO}_{2}$. Monolayer cells were trypsinized once they reached 80\% confluency (Masters, 2000).

Cell counting: Accurate cell number in the suspension was calculated using the haemocytometer (Soliman et al, 2013). Briefly, double fold dilution of the original cell suspension was prepared by adding $0.5 \mathrm{~mL}$ of undiluted cell suspension to $0.5 \mathrm{~mL}$ of $0.4 \%$ trypan blue dye.The mixture was mixed well and immediately aspirated to fill the haemocytometer counting chambers.

Cytotoxicity using colorimetric assay (MTT): Hep G2 cell line was seeded in the 96- well tissue culture plate with $100 \mu \mathrm{L}$ of RPMI medium. $200 \mu \mathrm{L}$ of tested materials serial dilution was done using two fold dilutions. The plates were then incubated with the various concentrations of each bee venom and curcumin for $24 \mathrm{~h}$ at $37^{\circ} \mathrm{C}$. The plates were read using ELISA reader at wavelength $570 \mathrm{~nm}$ and the absorbance was correlated with the cell number. The cytotoxic effects of the tested venom and curcumin on the Hep G2 cell lines were expressed as the IC50 value. Inhibitory concentration (IC50) of the compounds was assessed by Master-plex software (2010).

Morphology by inverted microscope. Untreated and treated Hep G2 cell line with bee venom and curcumin were examined for changes, $24 \mathrm{~h}$ post treatment using an inverted phase contrast microscope.

Flow cytometry cell cycle analysis using Propidium iodide DNA staining: For cell cycles analyzed by FACS, HepG2 cell line was seeded in DMEM with $10 \%$ FBS, then fixed in cold $70 \%$ ethanol on 6-well plates and allowed to attach overnight. While vortexing, the pellet was added drop wise. All cells were fixed for $30 \mathrm{~min}$ at $4{ }^{\circ} \mathrm{C}$ and minimized clumping. After ensuring fixation, the cells were washed in PBS and spun at $850 \mathrm{~g}$ in a centrifuge. Supernatant was discarded especially after spinning out of ethanol. Cells were treated with ribonuclease I $(100 \mathrm{mg} / \mathrm{ml}$ stock solution). $50 \mu \mathrm{l}$ of a $100 \mu \mathrm{g} / \mathrm{ml}$ sock of RNase was added to ensure only DNA not RNA was stained. $200 \mu 1$ propidium iodide was added $(50 \mu \mathrm{g} / \mathrm{ml}$ stock solution).

Apoptosis analysis by using Annexin VFITC Assay: 1-5 x 105 cells were collected by centrifugation, re-suspended in $500 \mu l$ of $1 \mathrm{X}$ Binding Buffer. $5 \mu \mathrm{l}$ of Annexin V-FITC $\& 5 \mu \mathrm{l}$ of propidium iodide (PI $50 \mathrm{mg} / \mathrm{ml}$ ) were added. Incubation was done at room temperature for $5 \mathrm{~min}$ in the dark. Annexin 
V-FITC binding was analyzed by flow cytometry $(\mathrm{Ex}=488 \mathrm{~nm} ; \mathrm{Em}=530 \mathrm{~nm})$ using FITC signal detector and PI staining by phycoerythrin emission signal detector. For adherent cells, they were gently trypsinized and washed once with serum-containing media before incubation with Annexin VFITC. Stained cells were analyzed for apoptotic cells $\%$ by Partec flow cytometer and FloMax software.

RNA Extraction and Quantitative RTPCR: Total RNA was extracted using Trizol reagent (Invitrogen, Carlsbad, CA, USA). Reverse-transcribed complementary DNA was synthesized using the Prime Script RT reagent kit (TaKaRa, Otsu, Japan). Realtime polymerase chain reaction was performed using SYBR Premix ExTaq (TaKaRa, Otsu, Japan) on an ABI Step One Real-Time PCR System (Applied Biosystem, Carlsbad, CA, USA). The amount of mRNA for each gene was normalized by GAPDH, and the relative expression levels were calculated using the $2-\Delta \Delta \mathrm{Ct}$ method. The primer sequences of the oligonucleotides used for PCR were as follows in relative quantification for the genes $(\beta$-actin, P53, Bcl-2, and NF-kB).

Primer sequences for genes

\begin{tabular}{|l|l|l|}
\hline Gene & \multicolumn{1}{|c|}{ Primers sequences } & Annealing temperature \\
\hline \multirow{3}{*}{$\beta$-actin } & F 5'GTGACATCCACACCCAGAGG 3' & $52^{\circ} \mathrm{C}$ \\
\cline { 2 - 3 } & R 5'ACAGGATGTCAAAACTGCCC 3' & $52^{\circ} \mathrm{C}$ \\
\hline \multirow{3}{*}{ P53 } & F 5' CCCCTCCTGGCCCCTGTCATCTTC 3' & $53^{\circ} \mathrm{C}$ \\
\cline { 2 - 3 } Bcl-2 & R 5'GCAGCGCCTCACAACCTCCGTCAT 3' & $51^{\circ} \mathrm{C}$ \\
\cline { 2 - 3 } & F 5'CCTGTG GAT GAC TGA GTA CC 3' & $49^{\circ} \mathrm{C}$ \\
\hline \multirow{2}{*}{$\begin{array}{l}\text { NF- } \\
k B\end{array}$} & F 5'GAGACA GCC AGG AGA AAT CA 3' & $47^{\circ} \mathrm{C}$ \\
\cline { 2 - 3 } & R 5'-GGCAGAGCACGTGGGACCTG -3' & $55^{\circ} \mathrm{C}$ \\
\hline
\end{tabular}

F: Forward strand and R: Reverse strand .One mixed and left $10 \mathrm{~min}$ in dark at $25^{\circ} \mathrm{C}$ the absorbance of the supernatant was measured photometrically at $540 \mathrm{~nm}$.

Statistical analyses: All experiments were performed in triplicate unless specified, represented as the mean \pm SEM. Analysis was performed using unpaired Student's t test. Groups were compared by one-way ANOVA with Dunnett's posttest. P values $<0.05$ were considered significant and $\mathrm{p}<0.01$ highly significant. Cytotoxicity using colorimetric as-say (MTT) showed that doxorubi
Cin drug and bee venom inhibited cancer cells growth. Liver cell line (Hep-G2) was treated with combination of DOX and bee venom against anticancer chemotherapy growth inhibitory, effects were performed and evaluated using MTT assay.

\section{Results}

The results are shown in tables $(1,2,3,4$, $5 \& 6$ ) and figures ( 1 to 7 ).

Table 1: Effect of doxorubicin drug with bee venom against drug doxorubicin only on inhibitory effect on Hep-G2 liver cancer cell line

\begin{tabular}{|l|l|l|l|}
\hline \multirow{2}{*}{$\begin{array}{l}\text { IC50 } \\
\text { ug/mL) }\end{array}$} & DOX & B.V & DOX+B.V \\
\cline { 2 - 4 } & 217 & 31 & 66.36 \\
\hline
\end{tabular}

Cytotoxic effect of bee venom and doxorubicin on Hep-G2 was expressed as $\mathrm{IC}_{50}$ value; the drug concentration reduced the absorbance of treated cells by $50 \%$ with respect to untreated cells. Inhibitory concentration $\left(\mathrm{IC}_{50}\right)$ was assessed by master pellex software. Bee venom and DOX showed significantly high growth inhibitory effects on Hep-G2 liver cancer cell line in a concentration dependent manner compared to bee venom alone. Bee venom was selected to detect pro-apoptotic such as (P53) gene and anti-apoptotic (bcl-2) gene expression levels in cell lines post treatment. $\mathrm{IC}_{50}$ measured for Hep-G2, and for doxorubicin drug was $217 \mu \mathrm{g} / \mathrm{mL}$, bee venom was $31 \mu \mathrm{g} / \mathrm{mL}$, and doxorubicin with bee venom was $66.36 \mu \mathrm{g} /$ $\mathrm{mL}$. DOX was more toxic than bee venom alone or with bee venom (Fig. 1, Tab. 1). 
Table 2: Effect of curcumin, curcumin with DOX, and combination of curcumin \& DOX with bee venom against doxorubicin drug on inhibitory effect on Hep-G2 liver cancer cell line

\begin{tabular}{|l|l|l|l|}
\hline $\begin{array}{l}\text { IC50 } \\
(\mathrm{ug} / \mathrm{mL})\end{array}$ & Curcumin & Curcumin + DOX & $C B D$ \\
\cline { 2 - 4 } & 15.15 & 77.30 & 348.00 \\
\hline \multicolumn{3}{|c|}{ CBD $=$ respective on Hep-G2 cell line. }
\end{tabular}

Cytotoxic effect of the bee venom as well as doxorubicin on Hep-G2 was expressed as $\mathrm{IC}_{50}$ value; drug concentration reduced the absorbance of treated cells by $50 \%$. Inhibitory concentration $\left(\mathrm{IC}_{50}\right)$ of compound assessed by master pellex software. Combination of CBD showed significantly high growth inhibitory effects on Hep-G2 liver cancer cell line in a concentration dependent manner compared to curcumin only or with doxorubicin drug. So, curcumin and bee venom were selected to detect the pro- apoptotic (P53) gene and anti-apoptotic (bcl2) gene expression levels in cell lines post treatment.

$\mathrm{IC}_{50}$ for curcumin was $15.15 \mu \mathrm{g} / \mathrm{mL}$, curcumin \& doxorubicin drug was $77.5 \mu \mathrm{g} / \mathrm{mL}$ and combination of curcumin and doxorubicin with bee venom was $348.00 \mu \mathrm{g} / \mathrm{mL}$. So, $C B D 348.00 \mu \mathrm{g} / \mathrm{mL}$ was more toxic than curcumin only or with DOX. So, curcumin and bee venom determined their effect on pro-apoptotic and anti-apoptotic gene expression level post treatment (Fig. 2)

Table 3: Effect of cell cycle concentration on HepG2 cell line by different samples

\begin{tabular}{|l|l|c|c|c|c|c|}
\hline ser & Sample code & $\% \mathrm{G} 0-\mathrm{G} 1$ & $\% \mathrm{~S}$ & $\% \mathrm{G} 2 / \mathrm{M}$ & $\%$ PreG1 & Comment \\
\hline 1 & D (DOX) & 66.02 & 21.84 & 12.14 & 10.29 & PreG1apoptosis\&Cell growth arrest@ G2/M \\
\hline 2 & Cur (Curcumin) & 62.86 & 18.92 & 18.22 & 16.4 & PreG1apoptosis\&Cell growth arrest@ G2/M \\
\hline 3 & B (BV) & 64.32 & 22.46 & 13.22 & 11.29 & PreG1apoptosis\&Cell growth arrest@ G2/M \\
\hline 4 & D+B & 64.28 & 21.13 & 14.59 & 11.39 & PreG1apoptosis\&Cell growth arrest@ G2/M \\
\hline 5 & D+C & 56.41 & 17.33 & 26.26 & 24.31 & PreG1apoptosis\&Cell growth arrest@ G2/M \\
\hline 6 & D+C+B & 59.62 & 24.2 & 16.18 & 13.38 & PreG1apoptosis\&Cell growth arrest@ G2/M \\
\hline 7 & cont. HepG2 & 69.32 & 27.91 & 2.77 & 2.47 & \\
\hline
\end{tabular}

In HepG2 cells, DOX sample cell population was G0-G1, G2/M, S, \& Pre-G1 phases from $66.02 \mathrm{ug} / \mathrm{ml}, 21.84 \mathrm{ug} / \mathrm{ml}, 12.14 \mathrm{ug} / \mathrm{ml}$, and $10.29 \mathrm{ug} / \mathrm{ml}$. then cur in G0-G1, G2/M, $\mathrm{S}, \quad \&$ Pre-G1phases from $62.86 \mathrm{ug} / \mathrm{ml}$, $18.92 \mathrm{ug} / \mathrm{ml}, 18.22 \mathrm{ug} / \mathrm{ml}, \& 16.4 \mathrm{ug} / \mathrm{ml}$. BV indicated in G0-G1, G2/M, S, \& Pre-G1 phases from $64.32 \mathrm{ug} / \mathrm{ml}, 22.46 \mathrm{ug} / \mathrm{ml}, 13.22$ $\mathrm{ug} / \mathrm{ml}$, \& $11.29 \mathrm{ug} / \mathrm{ml}$. Combination of DOX \& bee venom in G0-G1, G2/M, S, \& PreG1phases from $64.28 \mathrm{ug} / \mathrm{ml}, 21.13 \mathrm{ug} / \mathrm{ml}$, $14.59 \mathrm{ug} / \mathrm{ml}, \& 11.39 \mathrm{ug} / \mathrm{ml}$. and in combination of DOX \& curcumin $(\mathrm{D}+\mathrm{C})$ in $\mathrm{G} 0-\mathrm{G} 1$, G2/M, S, \& Pre-G1 phases from 56.41ug/ $\mathrm{ml}, 17.33 \mathrm{ug} / \mathrm{ml}, 26.26 \mathrm{ug} / \mathrm{ml}$, \& $24.31 \mathrm{ug} / \mathrm{ml}$. depended combination of G0-G1, G2/M, S,
\& Pre-G1phases from $59.62 \mathrm{ug} / \mathrm{ml}$, $24.2 \mathrm{ug} / \mathrm{ml}, 16.18 \mathrm{ug} / \mathrm{ml}, \& 13.38 \mathrm{ug} / \mathrm{ml}$. Control Hep G2 cell line showed G0-G1, G2/M, $\mathrm{S}$, \& Pre-G1phases as $69.32 \mathrm{ug} / \mathrm{ml}, 27.91 \mathrm{ug} /$ $\mathrm{ml}, 2.77 \mathrm{ug} / \mathrm{ml}, \& 2.47 \mathrm{ug} / \mathrm{ml}$ respectively..

Induction of cell cycle arrest in $\mathrm{G} 0 / \mathrm{G} 1, \mathrm{~S}$, $\mathrm{G} 2 / \mathrm{M}$ and apoptosis phases after $24 \mathrm{~h}$ of incubation of HepG2 cell line (Fig. 3), accumulated in G0/G1 phase (purple columns) of cell cycle, but proportion of cells in $\mathrm{S}$ phase (violet columns) decreased on six combination in independent experiments. When compared to arrest in G2/M phase (yellow columns) and apoptosis (aqua columns) in HepG2 cell differed from proportion of cells in G0/G1 phase of cell cycle.

Table 4: Effect of different stages of apoptosis (cell death program) on HepG2cell line.

\begin{tabular}{|l|l|l|l|l|l|}
\hline$\underline{\text { Ser }}$ & Sample & $\underline{\text { Total }}$ & $\underline{\text { Early }}$ & $\underline{\text { Late }}$ & $\underline{\text { necrosis }}$ \\
\hline$\underline{1}$ & $\underline{\mathrm{D}(\mathrm{DOX})}$ & $\underline{10.29}$ & $\underline{3.86}$ & $\underline{4.36}$ & $\underline{2.07}$ \\
\hline$\underline{2}$ & $\underline{\text { Cur (Curcumin) }}$ & $\underline{16.4}$ & $\underline{6.52}$ & $\underline{7.89}$ & $\underline{1.99}$ \\
\hline$\underline{3}$ & $\underline{\mathrm{B}(\mathrm{BV})}$ & $\underline{11.29}$ & $\underline{4.48}$ & $\underline{5.07}$ & $\underline{1.74}$ \\
\hline$\underline{4}$ & $\underline{\mathrm{D}+\mathrm{B}}$ & $\underline{11.39}$ & $\underline{4.17}$ & $\underline{5.27}$ & $\underline{1.95}$ \\
\hline$\underline{5}$ & $\underline{\mathrm{D}+\mathrm{C}}$ & $\underline{24.31}$ & $\underline{10.55}$ & $\underline{9.76}$ & $\underline{4.0}$ \\
\hline$\underline{6}$ & $\underline{\mathrm{D}+\mathrm{C}+\mathrm{B}}$ & $\underline{13.38}$ & $\underline{5.49}$ & $\underline{5.87}$ & $\underline{2.02}$ \\
\hline$\underline{7}$ & $\underline{\text { cont HepG} 2}$ & $\underline{2.47}$ & $\underline{0.89}$ & $\underline{0.75}$ & $\underline{0.83}$ \\
\hline
\end{tabular}


early, late, and necrosis stages was 11.39, $4.17,5.27, \& 1.95$. The DOX with curcumin gave high significant in total, early, late, and necrosis stages as $24.3,10.55,9.76, \& 4.0$. Combination between bee venom, curcumin, and DOX gave best effect on live cancer cell line in total, early, late, and necrosis stages as $13.38,5.49,5.87 \backslash \& 2.02$ respectively.
Effect of (DOX) in total, early, late, and necrosis stages arranged10.29, 3.86, 4.36, \& 2.07. also, in Cur (Curcumin) in total, early, late, and necrosis stages arranged 16.4, 6.52, 7.89, \&1.99. and bee venom as antioxidant $\mathrm{B}(\mathrm{BV})$ gave good in total, early, late, and necrosis stages as $11.29,4.48,5.07, \& 1.74$. Combination of DOX \& bee venom in total,

Table 5: Relative Bcl2, p53, and NFkB gene expression in HepG2 cell line according to sample data

\begin{tabular}{|l|l||l|l|l|}
\hline Ser & Sample code & P53 & Bcl2 & NFkB \\
\hline 1 & D (DOX) & 8.962536 & 0.306488 & 7.826363 \\
\hline 2 & Cur (Curcumin) & 11.37421 & 0.147549 & 11.16162 \\
\hline 3 & B (BV) & 10.11092 & 0.522225 & 8.08324 \\
\hline 4 & D+B & 7.62008 & 0.586194 & 10.97516 \\
\hline 5 & D+C & 15.16802 & 0.194713 & 14.48009 \\
\hline 6 & D+C+B & 9.507292 & 0.329361 & 10.78922 \\
\hline 7 & cont. HepG2 & 1 & 1 & 1 \\
\hline
\end{tabular}

compared with those of house-keeping gene as relative fold expression change. A high value depicts a higher expression level in P53, but a less one showed a lower expression in tumor relative to liver samples (NFkB \& Bcl2).
Gene expression level of pro-apoptotic gene as p53 and anti-apoptotic gene as Bcl-2 and $\mathrm{NFkB}$ were examined in cell lines post treatment with $\mathrm{IC}_{50}$ of curcum in, DOX, \& bee venom compared to control by PCR (Fig. 5). Duplicated data were normalized

Table.6a: Gene expression level of Bc12 in quantitation data with control and test cell

\begin{tabular}{|c|c|c|c|c|c|c|c|c|c|}
\hline \multirow{2}{*}{$\mathbf{A}$} & \multirow[t]{2}{*}{ Sample data } & \multicolumn{8}{|c|}{ Bcl2 } \\
\hline & & \multicolumn{3}{|c|}{ Control cells } & \multicolumn{4}{|c|}{ Test cells } & \multirow{2}{*}{$\begin{array}{l}\text { FLD } \\
2^{\wedge} \Delta \Delta C T\end{array}$} \\
\hline $\mathrm{Se}$ & \multirow[t]{2}{*}{$\begin{array}{l}\text { Sample code } \\
\text { Conc. yM }\end{array}$} & $\begin{array}{c}\text { B } \\
\text { Actin }\end{array}$ & $\mathrm{Bcl} 2$ & $\Delta \mathrm{CTC}$ & B Actin & $\mathrm{Bcl} 2$ & $\Delta \mathrm{CTE}$ & $\Delta \Delta \mathrm{CT}$ & \\
\hline & & $\mathrm{HC}$ & $\mathrm{TC}$ & HC-HE & $\mathrm{HE}$ & TE & TC-TE & $\Delta \mathrm{CTE} / \Delta \mathrm{CTC}$ & Eamp $=1.849$ \\
\hline 1 & D (DOX) & 27.69 & 28.96 & 2.5 & 25.19 & 33.77 & -4.81 & -1.924 & 0.306488 \\
\hline 2 & Cur (Curcumin) & 27.69 & 28.96 & 1.5 & 26.19 & 33.63 & -4.67 & -3.11333 & 0.147549 \\
\hline 3 & B (BV) & 27.69 & 28.96 & 1.58 & 26.11 & 30.63 & -1.67 & -1.05696 & 0.522225 \\
\hline 4 & $\mathrm{D}+\mathrm{B}$ & 27.69 & 28.96 & 1.45 & 26.24 & 30.22 & -1.26 & -0.86897 & 0.586194 \\
\hline 5 & $\mathrm{D}+\mathrm{C}$ & 27.69 & 28.96 & 1.45 & 26.24 & 32.82 & -3.86 & -2.66207 & 0.194713 \\
\hline 6 & $\mathrm{D}+\mathrm{C}+\mathrm{B}$ & 27.69 & 28.96 & 1.45 & 26.24 & 31.58 & -2.62 & -1.8069 & 0.329361 \\
\hline
\end{tabular}

Table 6b: Gene expression level of p53 in quantitation data with control cell and test cell

\begin{tabular}{|c|c|c|c|c|c|c|c|c|c|}
\hline \multirow{2}{*}{\multicolumn{2}{|c|}{ B Sample data }} & \multicolumn{8}{|c|}{ p53 } \\
\hline & & \multicolumn{3}{|c|}{ Control cells } & \multicolumn{4}{|c|}{ Test cells } & FLD \\
\hline \multirow[t]{2}{*}{ Ser } & \multirow{2}{*}{$\begin{array}{l}\text { Sample code } \\
\text { Conc. yM! }\end{array}$} & B Actin & p53 & $\Delta \mathrm{CTC}$ & B Actin & p53 & $\Delta \mathrm{CTE}$ & $\Delta \Delta \mathrm{CT}$ & $2^{\wedge} \Delta \Delta \mathrm{CT}$ \\
\hline & & $\mathrm{HC}$ & TC & $\mathrm{HC}-\mathrm{HE}$ & $\mathrm{HE}$ & TE & TC-TE & $\triangle \mathrm{CTE} / \triangle \mathrm{CTC}$ & Eamp $=1.849$ \\
\hline 1 & D (DOX) & 27.69 & 34.27 & 1.25 & 26.44 & 29.81 & 4.46 & 3.568 & 8.962536 \\
\hline 2 & Cur (Curcumin) & 27.69 & 34.27 & 1.58 & 26.11 & 28.02 & 6.25 & 3.955696 & 11.37421 \\
\hline 3 & B (BV) & 27.69 & 34.27 & 1.06 & 26.63 & 30.28 & 3.99 & 3.764151 & 10.11092 \\
\hline 4 & $\mathrm{D}+\mathrm{B}$ & 27.69 & 34.27 & 1.25 & 26.44 & 30.14 & 4.13 & 3.304 & 7.62008 \\
\hline 5 & $\mathrm{D}+\mathrm{C}$ & 27.69 & 34.27 & 1.25 & 26.44 & 28.74 & 5.53 & 4.424 & 15.16802 \\
\hline 6 & $\mathrm{D}+\mathrm{C}+\mathrm{B}$ & 27.69 & 34.27 & 1.25 & 26.44 & 29.69 & 4.58 & 3.664 & 9.507292 \\
\hline
\end{tabular}

Table 6c: Gene expression level of NFkB in quantitation data with control cell and test cell

\begin{tabular}{|r|l|c|c|c|c|c|c|c|c|}
\hline \multirow{2}{*}{ C Sample data } & \multicolumn{9}{|c|}{ NFkB } \\
\cline { 3 - 10 } & \multicolumn{3}{|c|}{ Control cells } & \multicolumn{5}{c|}{ Test cells } & FLD \\
\hline \multirow{2}{*}{ Ser } & \multirow{2}{*}{$\begin{array}{c}\text { Sample code } \\
\text { Conc. yM }\end{array}$} & B Actin & Casp3 & $\Delta$ CTC & B Actin & Casp3 & \multicolumn{1}{|c|}{$\Delta$ CTE } & $\Delta \Delta$ CT & $2^{\wedge} \Delta \Delta$ CT \\
\cline { 3 - 11 } & HC & TC & HC-HE & HE & TE & TC-TE & $\Delta$ CTE/ $\Delta$ CTC & Eamp=1.849 \\
\hline 1 & D (DOX) & 27.69 & 33.52 & 1.18 & 26.51 & 29.57 & 3.95 & 3.347458 & 7.826363 \\
\hline 2 & Cur (Curcumin) & 27.69 & 34.69 & 2 & 25.69 & 26.84 & 7.85 & 3.925 & 11.16162 \\
\hline 3 & B (BV) & 27.69 & 34.78 & 1.8 & 25.89 & 28.66 & 6.12 & 3.4 & 8.08324 \\
\hline 4 & D+B & 27.69 & 34.78 & 1.66 & 26.03 & 28.31 & 6.47 & 3.89759 & 10.97516 \\
\hline 5 & D+C & 27.69 & 34.78 & 1.98 & 25.71 & 26.17 & 8.61 & 4.348485 & 14.48009 \\
\hline 6 & D+C+B & 27.69 & 34.78 & 1.92 & 25.77 & 27.35 & 7.43 & 3.869792 & 10.78922 \\
\hline
\end{tabular}




\section{Discussion}

No doubt, the toxic effect of DOX is a reason for concern that limits its usability. It provides an inadequate effect in addition to its effect on the cancer cells as well as the normal cells. Also, is one of the major problems of chemotherapy is the resistance developed after initial treatment. The problem of using chemotherapeutic drug has main factors of poor prognosis and advancement of liver cancer in the human. Thus, scientists participated in the design of the most powerful treatments to overcome this obstacle. It has been confirmed that defective apoptosis is one mechanism of latent chemical resistance in liver cancer (Jiang et al., 2013). This has led to the increased demand of using anticancer drugs developed from natural resources. The biodiversity of bee venom and curcumin makes them a unique source from which novel therapeutics may be developed. Curcumin and bee venom reported having potential cytotoxic effects on tumor cells. However, little is known about their cytotoxicity as crude venoms compared with their major components effects on the liver cancer. In the current study, the antiproliferative effects of curcumin and $\mathrm{BV}$ have been studied on the liver cancer cell. Bee venom inhibits the proliferation of carcinoma cell in a dose dependent way. The bee venom has the ability to induce apoptosis via Bcl-2 \& NF-k $\beta$ in down-regulation in signaling pathways. Curcumin-mediated growth inhibition and DNA damage in both mitochondria as well as the nucleus involved pro-oxidant mechanisms as evidenced by increased ROS and lipid peroxide levels in HepG2 cells. In a subsequent study showed that curcumin produced mitochondrial hyperpolarization, elevated mitochondrial membrane potential and also increased cytochrome $\mathrm{C}$ release in HepG2 cells. Up-regulation of the notch1 receptor and signaling pathways in hepatocarcinogenesis result in increased cellular proliferation as well as inhibition of apoptosis. Jurenka (2009) reported that the possible mechanisms respon- sible for the induction of apoptosis by curcumin inhibits of growth and induction of apoptosis in a dependent and independent way in liver cancer cells is via downregulating the expression of Bcl-2 and BclXL and up-regulating the expression of P53. Curcumin also affected p53 by modulating its phosphorylation at serine 15 and its acetylation in a concentration-dependent manner.

In the present study, bee venom inhibited tHepG2 cell proliferation and induced morphological changes that agreed with Premratanachai and Chanchao (2014) who confirmed that bee venom has an inhibitory effect on HepG2cell line after 24hrs treatment. Samarghandian et al. (2014) proved that HepG2 liver cancer cells showed morphological changes post $24 \mathrm{hrs}$ in a time and concentration dependent.

In the present study, cell proliferation inhibition and induction of morphological changes was observed that was in agreed with Ip et al. (2008) confirmed that bee venom posseesed an inhibitory effect on HepG2 cell line $24 \mathrm{hrs}$ post treatment. Regarding to measure the cytotoxicity of bee venom to HepG2 cell line the IC50 value was that was alignment with $31 \mu \mathrm{g} / \mathrm{m}$. Alizadehnohi et al. (2017) reported that the $\mathrm{IC}_{50}$ value of bee venom was $28.5 \mu \mathrm{g} / \mathrm{ml}$ which is almost equal to present data and induced decrease of cell viability and apoptosis in human A172 glioblastoma cancer cell line. Several cellular cytotoxicity mechanisms have been reported in different types of cancer cells such as cell cycle modifications, an effect on proliferation, growth inhibition, and induction of apoptosis / necrosis. Also, the anti-proliferative effect of $\mathrm{BV}$ has recently demonstrated on C33A cervical cancer cells. The present cytotoxicity of doxorubicin drug in HepG2 cell line treated with the IC50 was recorded with a value 217 $\mu \mathrm{g} / \mathrm{ml}$ after $24 \mathrm{~h}$ that was near to that of bee venom. This disagreed with the IC50 value $164 \mu \mathrm{g} / \mathrm{ml}$ after $24 \mathrm{~h}$ in the A549 lung (Qianet $a l, 2011)$ cancer cell line. the combination of 
bee venom and doxorubicin induced synergetic activity induced a decreased IC50 value compared with that on using both bee venom and Dox in a single form recording IC50 value in the order of $66.36 \mu \mathrm{g} / \mathrm{ml}$ after $24 \mathrm{~h}$, that was in accordance with (Jurenka, 2009) recording that the higher level of lung cancerA549 cell treatment with bee venom a Dox mix was attributed to the synergetic activity detected. Furthermore BV treatment did not affect viability of normal cells indicating a degree of specificity for malignant cells. Therefore, it seems that BV components can be good candidate for future clinical trials for cancer therapy. BV constitutes an enormous source of enzymes and bioactive peptides such as melittin and phospholipase A2 and its beneficial actions on tumor cells may be due the effects of a single or several constituents on the tumor cells. Regarding to measure the cytotoxicity of curcumin that use as anti-oxidant for treatment of liver cancer (HepG2) cell line treated, Curcumi showed a higher toxicity to liver cancer cells recording an IC50 value in the order of $15.5 \mu \mathrm{g} / \mathrm{ml}$ after $24 \mathrm{~h}$. The data agreed with Putriet al.(2016) who reported that the curcumin inhibited the proliferation of HepG2 cells in a dose and time dependent manner. The cell viability decreases steadily when the dose of Curcumin increases as well as the incubation time prolongs. The IC50 value of Curcumin against HepG2 cells was $45.7 \mu \mathrm{g} / \mathrm{ml}$. In vitro cytotoxicity evaluation indicates that Curcumin possesses a dosedependent cell inhibition effect against HepG2 cells with the activation of Caspase3 (Jiang et al, 2013). In the present study, there was a synergetic activity of Curcumin to Dox recording an IC50 value of $77.5 \mu \mathrm{g} / \mathrm{ml}$ after $24 \mathrm{~h}$., which agreed with $\mathrm{Pu}-$ tri et al. (2016) recording that IC50 calculated post lung cancer cell line (A549) was 72 $72 \mu \mathrm{g} / \mathrm{ml}$. Also, the result synergetic activity of the 3 mix induced an antagonistic activity recording a higher IC50 value $348 \mu \mathrm{g} / \mathrm{ml}$ and that pro and anti-apoptotic gene (P53BCL-2) Curcumin and bee venom were se- lected to detect the pro-apoptotic such as (P53) gene and anti-apoptotic (bcl-2) gene expression levels in the cell lines after the treatment.

Cell cycle arrest is a common feature of cells that are undergoing terminal differentiation and defective proliferation. Based on the growth inhibitory and loss of membrane integrity on HepG2 cell lines, the cell cycle indicated that the cytotoxicity caused by doxorubicin might be derived from its potency in inducing marked apoptotic cell death after $24 \mathrm{hrs}$ incubation, apoptotic cell death was the main contributor to toxicity, while the accumulation in the $\mathrm{G} 2 / \mathrm{M}$ phase was decreased after 24 hours. Doxorubicin is classified as an antitumor antibiotic, made from natural products produced by species of the soil fungus Streptomyces. It acts during multiple phases of the cell cycle and the cytotoxic effect of doxorubicin are generally considered to be cell-cycle specific where accumulation in $\mathrm{G} 2 / \mathrm{M}$ phase can normally be detected in doxorubicin treated HepG2 (Qian et al, 2011). Another supporter to the effect of cell cycle on doxorubicin drug that interact with the cellular DNA while cells are in either S-phase or G2/M-phase inducing cell cycle arrest at G2/M-phase, also called mitoticcrises/catastrophe . It was reported that agents inducing S-phase accumulation sensitize tumorcells to the killing effect of doxorubicin. Regarding the cell cycle profile it was noticed that our result was in accordance with that Alizadehnohi et al.,( 2017) recording that the effect of bee venom and Dox on human lung (A549) induced pre G1 apoptosis and cell cycle arrest at G2/M and cell apoptosis may be attributed to the extrinsic path way and the and polyphenols, phenolic acids and vitamins, epicatechin and gallic acid are the most abundant that affecting death receptors (DR) leading to apoptosis in A549 through the interaction with TNF cytokine family such as tumor necrosis factor (TNF) with death receptor 1 (DR1), Fas Ligand (FASL) with death receptor 1 (DR2) \& Apo3 ligand 
(Apo3L) with death receptor 3 (DR3). Cell death and apoptosis might be due to the elevated antioxidants and anti-inflammatory, anti-mutagenic, and anticancer activities (Premratanachai and Chanchao, 2014). Currently combination of doxorubicin and curcumin-induced defects in mitotic events were paralleled by a significant increase in tumor cell G2/M arrest, suggesting that curcumin-induced suppression in cell growth. The induction of apoptosis was characterized by the accumulation of cells at the subG1 phase and increase in liver cancer cells. The inhibitory role of curcumin was due to the induction of cell arrest and apoptosis. Curcumin itself is a potent anticancer agent. Phase III clinical trials are undergoing to evaluate the effects of curcumin against pancreatic and liver cancers (Hatcher et al, 2008). Possible antitumor activity of curcumin and doxorubicin includes induction of tumor apoptosis and inhibition of tumor proliferation, invasion, angiogenesis, and metastasis. Numerous targets regulated by curcumin and doxorubicin consisting of kinases, enzymes, growth factors, cytokines, and transcription factors. In several studies, curcumin-induced p53-dependent apoptosis and G2/M arrest. p53, a tumor suppressor and a key regulator of cell survival and cell cycle progression in p53 mutated cell line the antitumor efficacy of curcumin proceeding via inhibition of HepG2cells must be p53independent.In the present study, cell cycle and apoptotic profile post application of bee venom-curcumin-Doxorubicin mix to liver cancer showed cell arrest and apoptotic profiles differently than use of each product in a single form. The regulation of apoptosis in normal and malignant cells has become an area of extensive study in cancer research. The apoptotic process is involved in the growth and inhibition of the tumor cells. In the present study, the examination of apoptotic regulatory effect of the tested venoms and their components as well as their combinations in liver cancer through the increase in expression intensity of P53, Bax and de- creased Bcl2 resembling that approved by different studies on the relation of bee venom their cancer cell death by apoptotic process. Curcumin-mediated growth inhibition and DNA damage in both mitochondria as well as the nucleus involved pro-oxidant mechanisms as evidenced by increased ROS and lipid peroxide levels in HepG2 cells. In a subsequent study, showed that curcumin produced mitochondrial hyperpolarization, elevated mitochondrial membrane potential (MMPs) and also increased cytochrome $C$ release in HepG2 cells. Up regulation of the P53 receptor and signaling pathways in hepatocarcinogenesis increased cellular proliferation and inhibited apoptosis.

In the present study, P53 was up-regulated gene and down regulated $\mathrm{NF}-\mathrm{k} \beta$ and Bcl-2. Tumor suppressor P53 frequently altered target in doxorubicin-resistant HCC, which is one of the key DNA damage sensors that transcriptional activator of proapoptotic factors including Bax, Bak. Doxorubicin up-regulates P53 which occurs through its phosphorylation by DDR kinases that inhibit its binding to and phosphorylation by MDM2, part of pathway of constitutive ubiquitination and proteosomal degradation that normally leads to low steady-state levels of P53 An inhibitor of MDM2-P53 binding, Nutlin-3 enhanced P53 stabilization and activation, and increased doxorubicin sensitivity in HCC cells with wild-type P53. Mutation or deletion of P53, or disruption of P53 activation pathways were events in HCC tumorigenesis, providing a possible me-chanism for intrinsic resistance to doxorubicin. Increasing P53 was not the only way to enhance doxorubicin sensitivity as the three hepatoma cell line in HepG2 cells, which have wild-type P53 (Cox and Weinman, 2016).

In the present study, effect of curcumin on the expression of P53 was in these liver cells. It was significantly enhan- ced P53responsive P21 plays a key role in $\mathrm{G} 2 / \mathrm{M}$ arrest of the cell cycle and indicates that expression of the tumor suppressor P21, a po- 
tent cyclin-dependent kinase (CDK) inhibitor that response to a variety of conditions including DNA damage and terminal differentiation. Moreover, up-regulation of P21 was required for growth inhibition of human cancer cells. P21induction in response to DNA damage requires the function of the P53 tumor suppressor protein. However, P21 expression was shown to be induced in several cell lines by agents that cause terminal differentiation via P53-independent mechanism. The indu- ction of P21 and Bax by curcumin was associated with apoptosis induction. Curcumin caused cell cycle arrest and apoptosis in several tumor cell lines (Veeraraghavan et al, 2010). The activity and stability of bee venom on tumor suppressor protein p53 was negatively regulated by oncogenic proteins MDM2 and MDMX cellular process initiated by MDM2/MDMX binding to the $\mathrm{N}$-termi-nal transactivation domain of P53. The antagonists blocked P53-binding pocket of MDM2/MDMX killed tumor cells in vitro by reactivating the P53 pathway. Since MDM2 and MDMX act synergistically in tumor cells, they highly attractive molecular targets for anticancer drug development. Inhibiting interactions between P53 and MDM2 have an antiproliferative effect in some cancer cells. Since the tumor suppressor p53 inhibits tumor growth primarily through its ability to induce apoptosis, reactivation of P53 by trigger massive apoptosis and eliminate the tumor cells.NF- $\kappa \mathrm{B}$ of doxorubicin drug have a tumor promoting effect by signaling is activated by DNA damage and can have varying effects on subsequent apoptosis primarily through regulation of its target genes, such as Bcl-XL, NF- $\kappa \mathrm{B}$ has an anti-apoptotic effect in response to drugs in DNA such as doxorubicin although might be partially dependent on the cancer cell type. Few studied the NF- $\kappa B$ role in resistance to doxorubicin in HCC although it has been shown to be activated in HCC cells in response to doxorubicin and several studies have indicated that activation of NF- $\kappa \mathrm{B}$ is a mecha- nism by which a diverse set of stimuli generate an anti-apoptotic effect. Anti-apoptotic gene BAG-1 enhanced doxorubicin resistance by potentiating the NF- $\kappa \mathrm{B}$ transcriptional activity (Cox and Weinman, 2016). NF-kB in curcumin played a crucial role in signal transduction pathways involved in acute chronic inflammatory diseases and various types of cancer. NF-kB proteins reside in cytoplasm in an inactive state because the transition to nucleus at activation required activation of different kinases, phosphorylation, and degradation of NF-kB (Hatcher et al, 2008). Alizadehnohi et al. (2017) reported that bee venom on cancer cell growth depended on cancer cell types. The cancer cell growth inhibitory effect was correlated with the down-regulation of various cell proliferative genes regulated by NF- $\kappa \mathrm{B}$. In agreement, BV suppressed DNA binding activity of NF- $\kappa \mathrm{B}$. Also, decrease of NF- $\kappa B$ DNA binding activity was associated with $t$ inhibitory effect of $\mathrm{BV}$ on the I $\mathrm{KB}$ phosphorylation and nuclear translocation of p50 \& p65 in colon cancer cells. The present data showed that BV suppressed the expression of anti-apoptotic proteins like $\mathrm{Bcl}-2$, and increased the expression of proapoptotic proteins such as Bax, caspase-3, caspase- 8 and caspase- 9 regulated by NF- $\mathrm{NB}$ or might be a difference in doxorubicin the ability of sequence-specific to suppress Bcl2 and $\mathrm{Bcl}-\mathrm{xL}$ expression. In the present results greater suppression of Bcl-2 than Bcl$\mathrm{xL}$ was achieved, their differences did not fully affect chemotherapy. The differential effects of Bcl-2 and Bcl-xL on drug sensitivity might be unique to liver cancer. Despite similarities in function in Bcl-2 family proteins, that Bcl-2 and Bcl-xL were subjected to different regulatory mechanisms. Bcl-2 inhibits induced apoptosis by blocking cytochrome $c$ release; but $\mathrm{Bcl}-\mathrm{xL}$ did not affect insertion into mitochondrial membranes (Takahashi et al, 2003). Expression result showed Bcl-2 oncogene was down-regulated. This agreed with Zheng et al. (2015) and Alizadehnohi et al. (2017) who reported 
that in caspase cascade activation led to induction of apoptosis via activation of initiator caspases caspase- $2,-8, \&-10$, and initiator caspases cleave and activate effector caspases-3, - 6 \&-7.

\section{Conclusion}

1- Bee (Apis mellifera) venom and curcumin had anticancer effect. 2-curcumin and bee venom has an anti-cancer potential. 3-Anticancer potentials could be confirmed by upregulation and down-regulations of pro and anti-apoptotic ge-nes.

\section{Recommendations}

1- More cancer cell lines could be tested for verification of anti-cancer potentials of target test materials (curcumin and bee venom). 2- In-vivo application of anti-cancer potentials of tested materials using murine models. 3-Monitoring of biochemical changes pre and post treatment with anti-cancer agent regarding the antioxidant parameters (GTH, MDA, NO, ROS etc.).

\section{Acknowledgment}

The authors are grateful to Prof. Dr. Ayman Diab, Dean, Faculty of Biotechnology, and Prof. Dr. Gehan Safwat, Vice Dean, who kindly supporting and facilitating this work.

\section{References}

Bertuccio, P, Turati, F, Carioli, G, Rodriguez, T, Vecchia, C, 2017: Global trends and predictions in hepatocellular carcinoma mortality. J. Hepatol. 67, 2:302-9.

Alizadehnohi, A, Nabiuni, AA, Nazari, F M, Safaeinejad ZA, Irian, AA, 2017: Eva-luation of anticancer activity of some venomous animal toxins on human breast and colon cancer cell lines and related antioxidant profile. Int. J. Adv. Res. 5, 2:2036-53.

Bagi, CM, Andresen, CJ. 2010: Models of hepatocellular carcinoma and biomarker strategy. Cancers 2, 3:1441-52.

Cox, J, Weinman, S, 2016: Mechanisms of doxorubicin resistance in hepatocellular carcinoma. Hepat. Oncol. 3, 1:57-9.

Darvesh, AS, Aggarwal, BB, Bishayee, A, 2012: Curcumin and Liver Cancer: A Review. Curr. Pharmaceut. Biotechnol. 13, 1: 218-28.

Fesik, SW, 2005: Promoting apoptosis as a strategy for cancer drug discovery. Nat.
Rev. Cancer 5, 11:876-85.

Foozie Shane, et al, 2016: Formic Acid and Microwave Assisted Extraction of Curcumin from Turmeric (Curcuma Longa L.). Int. J. Engineer. 29:2-9.

Giménez-Bonafé, P, Tortosa, A, Pérez-To más, R, 2009: Overcoming drug resistance by enhancing apoptosis of tumor cells. Curr. Cancer Drug Targ. 9, 3:320-40.

Hatcher, H, Planalp, R, Cho, J, Torti, F M, Torti, SV, 2008: Curcumin: Fr ancient medicine to current clinical trials. Cell. Mol. Life Sci. 65, 11:1631-52.

Holah, NS, El-Azab, DS, Aiad, HA, Swe-ed, DM, 2015: Hepatocellular carcinoma in Egypt: epidemiological and histopathological properties. Menoufia Med. J. 28, 3:71-8.

Jurenka, JS, 2009: Anti-inflammatory properties of curcumin, a major constituent of Curcuma longa: A review of preclinical and clinical research. Alter. Med. Rev.14, 2:141-53.

Jiang, J, Jin, H, Liu, L, Pi, J, Yang, F, et al, 2013: Curcumin disturbed cell-cycle distribution of HepG2 cells via cytoskeletal arrangement. Scanning 35, 4:253-60.

Mahjoub, MA, Bakhshinejad, B, Sadeghizadeh, M, Babashah, S, 2017: Combination treatment with dendrosomalnano curcumin and doxorubicin improves anticancer effects on breast cancer cells through modulating CXCR4/NF- $\kappa$ B/Smo regulatory network. Mol. Biol. Report $\backslash 44$, 4:341-51.

Masters, JR, 2000: Animal cell culture. In: A Practical Approach. New York: Oxford University Press.

Oršolić, N, 2012: Bee venom in cancer th-erapy. Cancer Metast. Rev. 31, 1/2:173-94.

Premratanachai, P, Chanchao, C, 2014: Review of anticancer activities of bee prod- ucts. Asia-Pacif. J. Trop. Biomed. 4, 5:337-44.

Putri, H, Jenie, RI, Handayani, S, Kasti- an, R, Meiyanto, E, 2016: Combination of potassium pentagamavunon-0 \& doxorubic- in induces apoptosis and cell cycle arrest $\&$ inhibits metastasis in breast cancer cells. Asia Pacif. J. Cancer Prevent. 17, 5: 2683-8.

Qian, H, Yang, Y, Wang, X, 2011: Curcu- min enhanced adriamycin-induced human liverderived hepatoma $\mathrm{G} 2$ cell death by ac-tivation of mitochondria-mediated apoptosis and autophagy. Euro J. Pharm. Sci. 43, 3: 25-31.

Sharma, S, Tanwar, A, Gupta, DK, 2016: Curcumin: An adjuvant therapeutic remedy for 
liver cancer. Hepatoma Res. 62-70. DOI: 10. 20517/2394-5079.2015.59

Soliman, EM, Mahdy SE, Mosaad, WG, Hassanin, AI, El Sayed, EI, 2013: Effect of different inactivators on the efficacy of Egyptian foot and mouth disease SAT2 vaccine. J. Anim. Sci. Adv. 3, 8:391-9

Takahashi, M, Saito, H, Atsukawa, K, 2003: Bcl-2 prevents doxorubicin-induced apoptosis of human liver cancer cells. Hepatol. Res. 25, 192201.

Tornesello, ML, Buonaguro, L, Tatangelo, F, Botti, G, Izzo, F, et al, 2013: Mutations in TP53, CTNNB1 \& PIK3CA genes in hepatocellular carcinoma associated with hepatitis B and hepatitis C virus infections. Genomics 102, 2:74-83

Trumbeckaite, S, Dauksiene, J, Bernatoniene, J, Janulis, V, 2015: Knowledge, attitudes, and usage of apitherapy for disease prevention and treatment among undergraduate pharmacy students in Lithuania. Evid. Bas. Compl. Alternat. Med. 2015:172502.

Veeraraghavan, J, Natarajan, M, Herm- an, TS, Aravindan, N, 2010: Curcumin-altered P53-response genes regulate radiosensitivity in P53-mutant Ewing's Sarcoma Anticancer Res. 30, 10:4007-15.

Vinken, M, Rogiers, V, 2015: Protocols in in vitro hepatocyte research. Protocols in In-Vitro Hepatocyte Res. 1250:1-390.

Wong, Y, Wu, C, Lin, C, Chen, T, Chang, T, et al, 2015: Applying NGS data to find evolutionary network biomarkers from the early and late stages of hepatocellular carcinoma, Biomed. Res. Int. 2015:391475.

Zheng, J, Lee, HL, Ham, YW, Song, HS, Song, MJ, et al, 2015: Anti-cancer effect of bee venom on colon cancer cell growth by activation of death receptors \& inhibition of nuclear factor kappa B. Oncotarget. 6, 42: 44437-51.

\section{Explanation figures}

Fig. 1: A- Evaluation of IC50 of bee venom and doxorubicin on Hep-G2 cell line, B- Evaluation of IC50 of DOX on Hep-G2 cell line, CEvaluation of IC50 of B.V on Hep-G2 cell line, and D- Evaluation of IC50 of DOX with B.V on Hep-G2 cell line.

Fig. 2: A-Evaluation of IC50 of curcumin and curcumin with doxorubicin and combination of CBD on Hep-G2 cell line, B-Evaluation of IC50 of curcumin and curcumin with DOX on Hep-G2 cell line, and C-Evaluation of IC50 of curcumin, curcumin plus DOX, and CBD on Hep-G2 cell line.

Fig. 3: distribution of HepG2 cell line between cell cycle phases on control and treated samples

Fig. 4: Flow cytometry showed early \& late apoptosis and necrotic cells after treatment with several of combination compounds on HepG2 cell line.

Fig. 5: Continue flow cytometry showed early \& late apoptosis and necrotic cells after treatment with several of combination compounds on HepG2 cell line.

Fig. 6: Apoptosis analysis of a HepG2 cancer cell line. Respective cell \% in early \& late, and necrosis apoptosis for different time period in paragraph.

Fig. 7: Analysis of gene expression profiles of $\mathrm{p} 53, \mathrm{Bcl} 2, \& \mathrm{NFkB}$ by using real-time PCR. 



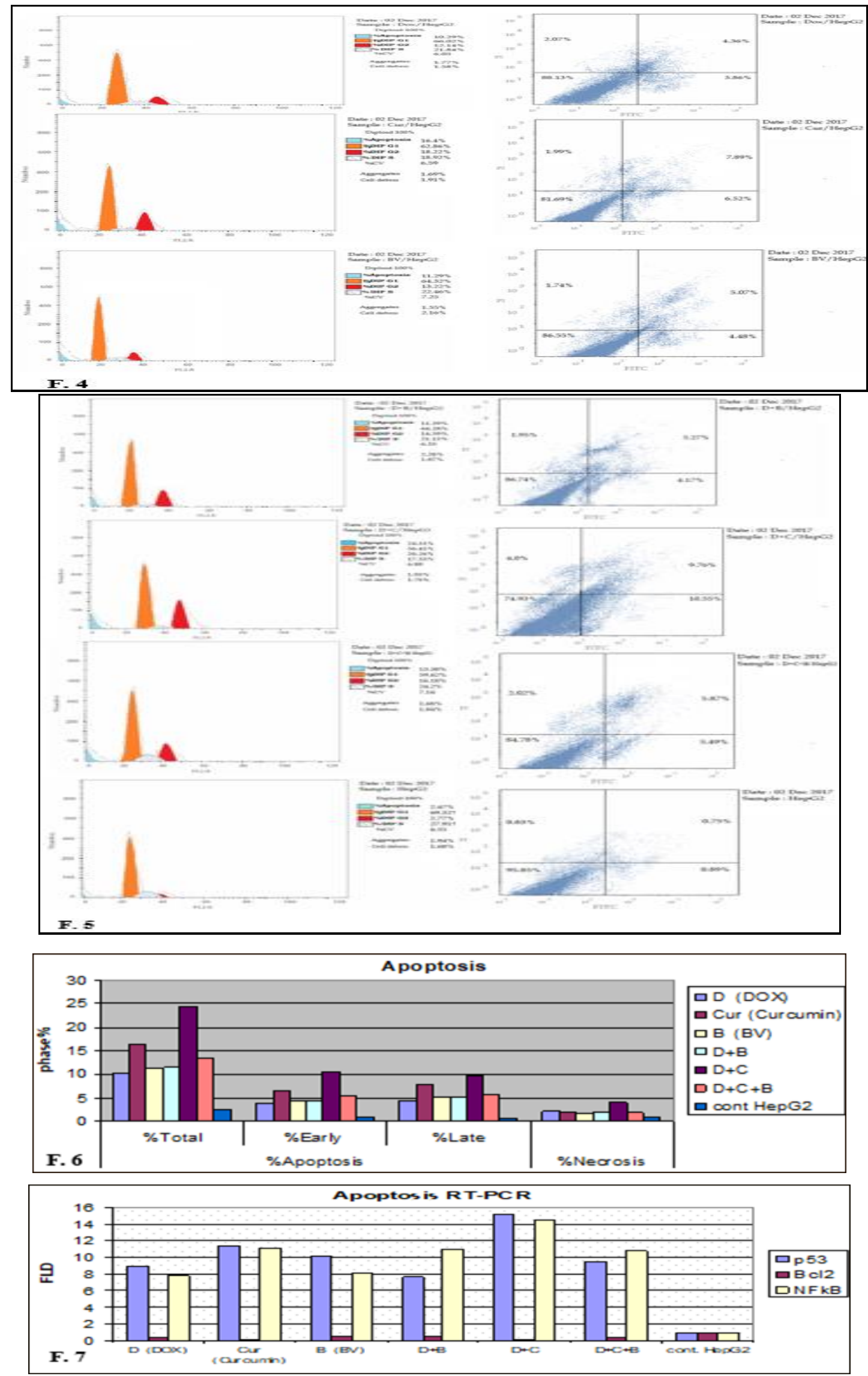